\title{
Different behaviour of inorganic and organic mercury in renal excretion with reference to effects of D-penicillamine
}

\author{
TSUGUYOSHI SUZUKIㄹ, SACHIKO SHISHIDO' ${ }^{1}$ and \\ NOBUO ISHIHARA ${ }^{2}$ \\ Department of Public Health ${ }^{1}$ and Department of Hygiene ${ }^{2}$, Tohoku University School \\ of Medicine, Sendai, Japan
}

\begin{abstract}
Suzuki, T., Shishido, S., and Ishihara, N. (1976). British Journal of Industrial Medicine, 33, 88-91. Different behaviour of inorganic and organic mercury in renal excretion with reference to effects of D-penicillamine. Inorganic and organic mercury was measured in the red cells, plasma, and urine of five laboratory workers to examine the effect of D-penicillamine. The workers had had no particular exposure to mercurials. Before and during administration of D-penicillamine, inorganic mercury levels in plasma were significantly correlated with those in urine or 24-hour urinary outputs, but no significant correlation was found for organic mercury. Administration of D-penicillamine enhanced 24-hour urinary output to a much greater extent in organic than inorganic mercury. All the organic mercury levels in blood, red cells, and plasma were increased by D-penicillamine. This contrasted with the decrease of inorganic mercury levels in plasma.
\end{abstract}

Oral administration of D-penicillamine unexpectedly enhanced the urinary excretion of organic, but not of inorganic mercury, in a patient poisoned with mercury vapour (Ishihara, Shiojima, and Suzuki, 1974). These authors considered that urinary excretion of organic mercury was selectively enhanced because most inorganic mercury was tightly bound to sites of great affinity to mercury in tissues and resistant to replacement with D-penicillamine at a relatively low dose level, but that organic mercury, on the contrary, was easily replaced by D-penicillamine.

To ascertain whether or not this speculation on the relationship of the selective effect of D-penicillamine with the level of exposure to inorganic mercury was true, personnel who had not been exposed to mercurials from occupational or pharmaceutical sources were selected in this study. In the patient described by Ishihara et al. (1974), inorganic and organic mercury were measured only in hair and urine.
In order to know the mechanism of the selective effect of D-penicillamine, it is essential to study the relationship between concentrations of mercury in plasma and urine. In this study, therefore, inorganic and organic mercury in red cells and in plasma were measured as well as in urine.

\section{Method and materials}

Subjects

Subjects studied were staff from our laboratory, comprising four men, aged between 27 and 42 years, and one woman aged 24 years. Mercury concentrations in blood and 24-hour urinary outputs of mercury before administration of D-penicillamine (Table) indicate that the body burden of these subjects is fully compatible with that of normal Japanese without any particular exposure to mercury, by comparison with the data already reported (Suzuki et al., 1971; Suzuki, Miyama, and Katsunuma, 1971 ; Takemoto et al., 1971 ; Kondo, 1971 ; Nishima et al., 1973; Suzuki and Shishido, 1974; Kondo et al., 1975). 
TABLE

Mercury Concentrations in Red Cells, Plasma, Blood, and Urine, and 24-h Outputs of Urinary Mercury before Administration of D-Penicillamine.

\begin{tabular}{|c|c|c|c|c|c|c|c|c|c|c|c|}
\hline \multicolumn{2}{|c|}{ Subjects } & \multirow{2}{*}{$\begin{array}{c}\text { Red cells } \\
(\mathrm{nmol} / \mathrm{l}) \\
\mathrm{O}-\mathrm{Hg}\end{array}$} & \multicolumn{2}{|c|}{$\begin{array}{l}\text { Plasma } \\
(\text { nmol/l) }\end{array}$} & \multicolumn{3}{|c|}{$\begin{array}{c}\text { Blood } \\
(\text { nmol/l) }\end{array}$} & \multicolumn{2}{|c|}{$\begin{array}{c}\text { Urine } \\
(\text { nmol/l) })\end{array}$} & \multicolumn{2}{|c|}{$\begin{array}{l}\text { 24-h outputs } \\
\text { of urinary } \mathrm{Hg} \\
(\text { nmol/24 h) }\end{array}$} \\
\hline Sex & $\begin{array}{c}\text { Age } \\
\text { (years) }\end{array}$ & & $I-H g$ & $\mathrm{O}-\mathrm{Hg}$ & $I-H g$ & $\mathrm{O}-\mathrm{Hg}$ & $T-H g$ & $I-H g$ & $\mathrm{O}-\mathrm{Hg}$ & $I-H g$ & $\mathrm{O}-\mathrm{Hg}$ \\
\hline $\begin{array}{l}\text { Male } \\
\text { Male } \\
\text { Male } \\
\text { Male } \\
\text { Female }\end{array}$ & $\begin{array}{l}42 \\
37 \\
36 \\
27 \\
24\end{array}$ & $\begin{array}{r}115.0 \\
198.5 \\
135.0 \\
186.0 \\
73.0\end{array}$ & $\begin{array}{l}5 \cdot 0 \\
4 \cdot 5 \\
6 \cdot 0 \\
3 \cdot 5 \\
4 \cdot 0\end{array}$ & $\begin{array}{r}7 \cdot 5 \\
12 \cdot 0 \\
15 \cdot 0 \\
10 \cdot 0 \\
3 \cdot 5\end{array}$ & $\begin{array}{l}2 \cdot 0 \\
2 \cdot 0 \\
2 \cdot 5 \\
1 \cdot 0 \\
2 \cdot 0\end{array}$ & $\begin{array}{r}70 \cdot 5 \\
111 \cdot 5 \\
80.0 \\
126.5 \\
35.5\end{array}$ & $\begin{array}{r}72 \cdot 5 \\
113.5 \\
82.5 \\
127 \cdot 5 \\
37 \cdot 5\end{array}$ & $\begin{array}{l}9 \cdot 3 \\
7 \cdot 5 \\
9 \cdot 9 \\
6 \cdot 4 \\
5 \cdot 3\end{array}$ & $\begin{array}{l}0.6 \\
0.7 \\
0.7 \\
1 \cdot 1 \\
0.8\end{array}$ & $\begin{array}{r}13.5 \\
7 \cdot 9 \\
17 \cdot 8 \\
6 \cdot 2 \\
6 \cdot 3\end{array}$ & $\begin{array}{l}0.9 \\
0.7 \\
1.2 \\
1.3 \\
1.0\end{array}$ \\
\hline \multicolumn{2}{|r|}{ age } & $141 \cdot 5$ & $4 \cdot 5$ & $9 \cdot 5$ & $2 \cdot 0$ & 85.0 & 87.0 & $7 \cdot 7$ & 0.8 & $10 \cdot 3$ & 1.0 \\
\hline
\end{tabular}

The values of mercury concentrations in urine and 24-h outputs of urinary mercury were the averages of the first and the second day

Mercury concentrations in blood were calculated from those in red cells and plasma from the value of haematocrit

$\mathrm{I}-\mathrm{Hg}$ : Inorganic mercury; $\mathrm{O}-\mathrm{Hg}$ : Organic mercury; $\mathrm{T}-\mathrm{Hg}$ : Total mercury

\begin{abstract}
Administration of D-penicillamine and collection of urine and blood

Urine was collected daily at 1.0 pm for six days. A daily dose of $5.4 \mathrm{mmol} D$-penicillamine was orally administered on the third and fourth day. The dose of D-penicillamine was the same as that given by Ishihara et al. (1974) to their patient. There were no adverse side-effects from the administration of D-penicillamine. Blood was obtained by venepuncture three times, that is, at the end of the first day, the third day (during the administration of D-penicillamine) and the sixth day. Blood samples were heparinized and separated into red cells and plasma by centrifugation.
\end{abstract}

\section{Measurements of mercury in biological samples}

Inorganic and organic mercury in red cells, plasma, and urine were measured using the method of Magos (1971) with a slight modification to eliminate the error due to the cleavage of organic mercury during the measuring procedure (Shishido and Suzuki, 1974). The sensitivity of the measurement of mercury was $2.5 \mathrm{pmol}$ for both inorganic and organic mercury. Altogether $2 \mathrm{ml}$ plasma, $1 \mathrm{ml}$ red cells, and $10 \mathrm{ml}$ urine were used for the measurement of mercury.

\section{Results}

Relationships between 24-hour urinary mercury outputs and plasma mercury concentrations

In the case of inorganic mercury, 24-hour urinary outputs on the second day were significantly correlated with levels in plasma at the end of the first day $(r=0.9306, P<0.05)$, but there was no significant correlation in the case of organic mercury (Fig. 1).

Effects of D-penicillamine on urinary mercury outputs and mercury concentrations in red cells and plasma Fig. 2 shows urinary inorganic and organic mercury

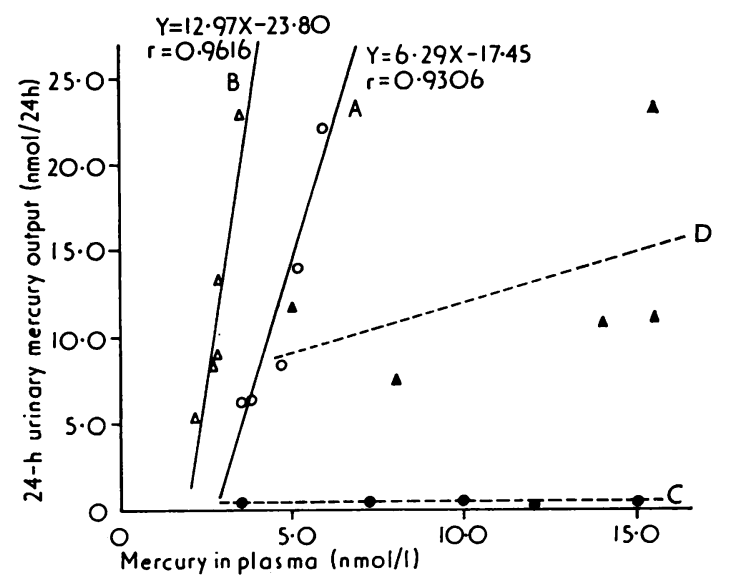

FIG. 1. Relationship between mercury concentrations in plasma and 24-hour urinary mercury outputs.

Inorganic mercury before administration of D-penicillamine (circle) and at administration (triangle); organic mercury before administration (solid circle) and at administration (solid triangle). A and B: Regression lines in terms of inorganic mercury at respective periods before and during administration. C and D: Regression lines in terms of organic mercury at respective periods before and during administration. Correlation coefficients and regression coefficients are significant only in $A$ and $B(P<0.05)$, but not C and D.

outputs for the entire period of the experiment. D-penicillamine markedly enhanced the output of urinary organic mercury. The average urinary output for the period (two days) of D-penicillamine administration was significantly raised compared to that obtained in the period before administration in the 

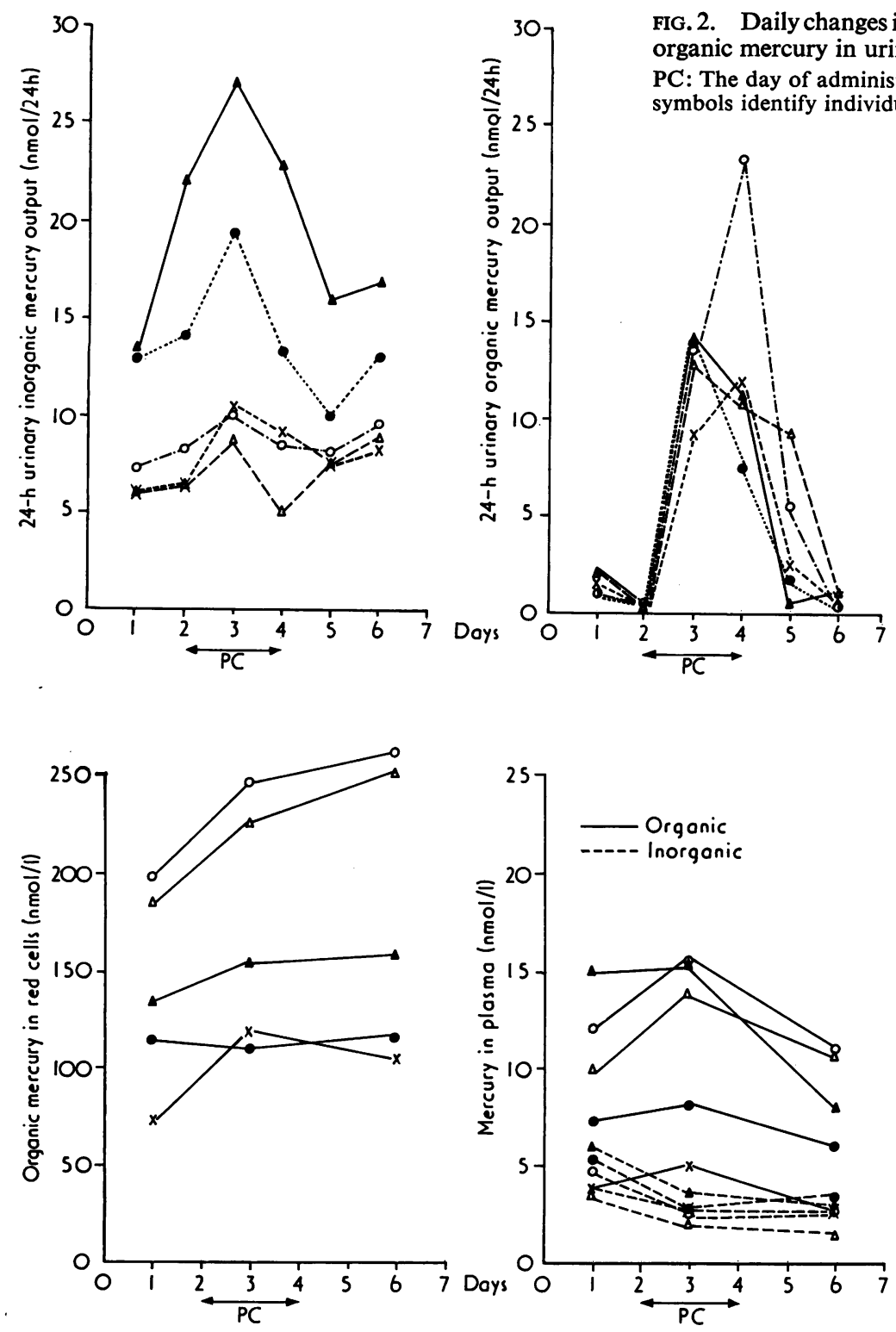

FIG. 3. Daily changes in mercury concentrations in red cells and plasma.

PC: The day of administration of D-penicillamine. Different symbols identify individuals.

case of organic mercury $(P<0.05)$. On the other hand, for inorganic mercury, the average period of administration was not significantly higher than that before administration, although the excreted amount on the first day of administration (the third day of the experiment) was significantly higher than the average of the period before administration $(P<0.05)$. The increase of urinary output was calculated as $3 \cdot 1 \mathrm{nmol}(0 \cdot 7-7 \cdot 1 \mathrm{nmol})$ for inorganic mercury and $11.75 \mathrm{nmol}(9 \cdot 45-17 \cdot 75 \mathrm{nmol})$ for organic mercury. These two increases differed significantly $(\mathrm{P}<0.01)$.
Changes in mercury levels in red cells and plasma are shown in Fig. 3. Organic mercury concentrations in red cells were raised by giving D-penicillamine, except in one case, and stayed at the higher level after administration. The average of both pre-administration and administration periods differed significantly $(P<0.05)$. The change of organic mercury in plasma contrasted with that of inorganic mercury in plasma. Organic mercury concentrations were increased by $D$-penicillamine and returned to the level of the period before administration after D-penicillamine. In contrast, inorganic mercury 
concentrations in plasma were decreased significantly $(\mathrm{P}<0.01)$ by $\mathrm{D}$-penicillamine and remained at the decreased level even after D-penicillamine.

Changes in relationships between 24-hour urinary mercury outputs and plasma mercury concentrations In the same way as in the period before administration, mercury levels at the end of the third day were matched with 24-hour urinary outputs on the fourth day, and a significant correlation was again found in the case of inorganic mercury, but not of organic mercury (Fig. 1).

\section{Discussion}

The speculation by Ishihara et al. (1974) to explain the selective effect of D-penicillamine for organic mercury excretion was based on the general difference between the binding of inorganic and organic mercury in tissues. The present results show that in relation to the binding of mercury in tissues, the fact that D-penicillamine increased the blood level of organic mercury and decreased that of inorganic mercury, the binding of organic mercury is much looser than that of inorganic mercury. Even in the period after administration, these effects due to D-penicillamine remained. These findings show that the transfer rate of inorganic mercury from tissues to blood is less than that of organic mercury after the disappearance of effects by D-penicillamine.

It has been suggested that the mercury of inorganic mercury in kidney tissue was bound to a protein thiol group by the first valence and to a non-thiol group, which had a higher affinity to maleate than to mercury, by the second valence (Magos, 1974). When this non-thiol binding site was occupied by mercury, the chance for penicillamine to compete with protein binding sites for mercury was considered to be much less than if this site was occupied by maleate. The relative ineffectiveness of $D$-penicillamine in accelerating urinary inorganic mercury excretion might thus be partly explained.

The main pathway in urinary excretion of mercury in any chemical form of mercurial compounds has been claimed to be tubular secretion (Vostal, 1968; Clarkson, 1972; Nordberg and Skerfving, 1972). If this is so, what is the meaning of the significant correlation between the plasma concentration and the 24-hour urinary output of inorganic mercury? Plasma concentrations of mercury might be just a reflection of the amount of mercury accumulated in the tubules. This experiment showed that although the plasma level of organic mercury was much higher than that of inorganic mercury, urinary excretionwas negligible, and administration of D-penicillamine without changing the plasma level of organic mercury increased its urinary excretion.

\section{References}

Clarkson, T. W. (1972). The pharmacology of mercury compounds. Annual Review of Pharmacology, 12, 375-406.

Ishihara, N., Shiojima, S., and Suzuki, T. (1974). Selective enhancement of urinary organic mercury excretion by D-penicillamine. British Journal of Industrial Medicine, 31, 245-249.

Kondo, M. (1971). Studies on the intake and excretion of heavy metals in the human being. Kankyo Hoken Report, 5, 47-64 (in Japanese).

- Mitani, K., Tsuchiya, H., Itaya, K., and Kondo, T. (1975). Mercury content in maternal blood, cord blood, and placenta. Japanese Journal of Hygiene, 30, 51 (Proceeding in Japanese).

Magos, L. (1971). Selective atomic-absorption determination of inorganic mercury and methylmercury in undigested biological samples. Analyst, 96, 847-853.

—- (1974). Binding sites for mercury and the synergism between penicillamine and maleate. Postgraduate Medical Journal, August Supplement, 22-23.

Nishima, T., Tada, T., Yagyu, H., and Nagasaki, M. (1973). Mercury content in blood and hair. Japanese Journal of Hygiene, 28, 58 (Proceeding in Japanese).

Nordberg, F. and Skerfving, S. (1972). Metabolism. In Mercury in the Environment, edited by L. Fiberg and J. Vostal, pp. 29-91. The Chemical Rubber Company, Cleveland.

Shishido, S. and Suzuki, T. (1974). Some technical problems in the selective measurement for inorganic and organic mercury by Magos. Japanese Journal of Industrial Health, 16, 274-275 (in Japanese).

Suzuki, T., Miyama, T., and Katsunuma, H. (1971). Comparison of mercury contents in maternal blood, umbilical cord blood, and placental tissues. Bulletin of Environmental Contamination and Toxicology, 5, 502-508.

- and Shishido, S. (1974). Change of levels of urinary organic mercury in groups with varying extents of inorganic mercury exposure. Tohoku Journal of Experimental Medicine, 112, 101-102.

- , Takemoto, T., Shimano, H., Miyama, T., Katsunuma, H., and Kagawa, Y. (1971). Mercury content in blood in relation to dietary habit of women without any occupational exposure to mercury. Industrial Health, 9, 1-8.

Takemoto, T., Suzuki, T., Miyama, T., and Nagao, $H$. (1971). Comparison of two methods for measuring minute amount of mercury in blood and hair. Japanese Journal of Industrial Health, 13, 46-47.

Vostal, J. (1968). Renal excretory mechanisms of mercury compounds (Working paper for the Symposium on MAC Values on Mercury, Stockholm). Karolinska Institute, Department of Environmental Hygiene, Stockholm, Sweden.

Received for publication 16 May 1975

Accepted for publication 25 November 1975 